\title{
Risk Factor Analysis of Overnutrition among Elementary School Children in Pekanbaru: An Urban-rural Perspective
}

\author{
Analisis Faktor Risiko Gizi Lebih pada Anak Sekolah Dasar di Perkotaan \\ dan Perdesaan Pekanbaru
}

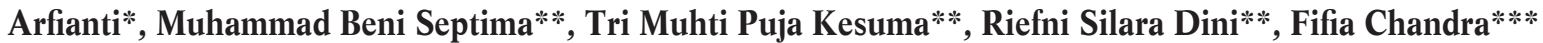

\begin{abstract}
*Medical Biology Department Faculty of Medicine Universitas Riau, Pekanbaru, Indonesia, **Faculty of Medicine Universitas Riau, Pekanbaru, Indonesia, ***Public Health Department, Faculty of Medicine, Universitas Riau, Pekanbaru, Indonesia
\end{abstract}

\begin{abstract}
The prevalence of childhood overnutrition is increasing in many parts of the world, including Indonesia. The 2010 National Basic Health Research study showed that the occurrence of overnutrition in urban children (10.4\%) was greater than in rural children (8.1\%). This study aimed to analyze risk factors for overnutrition among elementary school children in urban and rural areas in Pekanbaru. This was an observational analytical study with a cross-sectional design. This study involved 137 and 113 elementary school students from urban and rural areas, respectively. They were recruited from six elementary schools in Pekanbaru using the quota sampling technique. This study was conducted between April and May 2018. The results showed that the proportions of overweight and obesity in urban Pekanbaru were $16.1 \%$ and $16.8 \%$, respectively; in rural areas, the proportions were $12.4 \%$ and $9.7 \%$, respectively ( $p$ value $>0.05$ ). Furthermore, outdoor activity and snacking habits were significant contributors to childhood overnutrition in urban areas, whereas frequency of main meal was associated with childhood overnutrition in rural areas. In conclusion, there was no difference in the proportion of overnutrition among elementary students between urban and rural areas in Pekanbaru. This study indicated that obesity risk factors may be different between urban and rural areas in Pekanbaru.
\end{abstract}

Keywords: Diet, overweight, obesity, physical activities, screen time

\footnotetext{
Abstrak

Prevalensi gizi lebih pada anak mengalami peningkatan pesat di berbagai belahan dunia termasuk di Indonesia. Hasil Riset Kesehatan Dasar menunjukkan gizi lebih pada anak di perkotaan $(10,4 \%)$ lebih besar dibandingkan daerah pedesaan $(8,1 \%)$. Penelitian ini bertujuan menganalisis faktor risiko yang berhubungan dengan kejadian gizi lebih pada anak sekolah dasar di daerah perkotaan dan perdesaan di Pekanbaru. Jenis penelitian ini adalah penelitian observasional analitik dengan rancangan potong lintang. Penelitian ini melibatkan 137 anak di daerah perkotaan dan 113 anak di daerah perdesaan di Pekanbaru dengan teknik quota sampling. Penelitian ini dilakukan pada bulan April-Mei 2018. Hasil penelitian menunjukkan bahwa proporsi kegemukan dan obesitas di perkotaan Pekanbaru masing-masing sebesar $16,1 \%$ dan $16,8 \%$, sedangkan di pedesaan masing-masing sebesar $12,4 \%$ dan $9,7 \%$ (nilai $p$ > $0,05)$. Aktivitas di luar ruangan dan kebiasaan makan cemilan merupakan kontributor gizi lebih pada anak di perkotaan, sedangkan frekuensi makan utama merupakan satu-satunya faktor yang memengaruhi kejadian gizi lebih pada anak di pedesaan. Simpulan penelitian ini menunjukkan tidak terdapat perbedaan proporsi gizi lebih pada anak sekolah dasar antara daerah perkotaan dan pedesaan di Pekanbaru. Penelitian ini juga mengindikasikan bahwa faktor risiko obesitas berbeda antara daerah perkotaan dan pedesaan di Pekanbaru.

Kata kunci: Pola makan, kegemukan, obesitas, aktivitas fisik, screen time

How to Cite: Arfianti, Muhammad Beni Septima, Tri Muhti Puja Kesuma, Riefni Silara Dini, Fifia Chandra. Risk Factor Analysis of Overnutrition among Elementary School Children in Pekanbaru: An Urban-rural Perspective. Kesmas: National Public Health Journal. 2019; 13 (4): 182 190 (doi:10.21109/kesmas.v13i4.2639)

Correspondence: Arfianti, Medical Biology Department Faculty of Medicine Universitas Riau, Diponegoro street, No.1 Pekanbaru 28133, Indonesia, Phone: +62-761-839264, e-mail: evi_anti@yahoo.com

Received : September $7^{\text {th }} 2018$

Revised : February $4^{\text {th }} 2019$

Accepted : March 5 ${ }^{\text {th }} 2019$
} 


\section{Introduction}

Obesity is a global health problem in both developed and developing countries. In 2016, the World Health Organization (WHO) estimated that more than 340 million children and adolescents aged 5-19 years were obese. ${ }^{1}$ Developing countries experience a double burden of malnutrition wherever childhood undernutrition prevails, while childhood obesity is epidemic. According to 2013 National Basic Health Research, the proportions of obesity in children under five years old in Indonesia in 2007, 2010, and 2013 were $12.2 \%, 14 \%$, and $11.9 \%$, respectively. At the same time, undernutrition among children younger than 5 years is inevitable $(\sim 20 \%))^{2}$ In Riau Province, $10.6 \%$ of children aged 5-12 were overweight and $7.2 \%$ of these children were obese. With an obesity rate of $12.1 \%$, Pekanbaru places second among all Riau Province districts; only Rokan Hulu (12.3\%) has a more obese population. ${ }^{2}$

Pekanbaru is a business-oriented city with rapid economy growth, but some of Pekanbaru's districts are still classified as rural areas. Previous study showed that the prevalence of overnutrition in urban areas $(10.4 \%)$ was greater than in rural areas $(8.1 \%) .^{2}$ One study conducted in Denpasar, Bali (2013) reported that $21 \%$ of elementary school students living in urban areas were obese, compared to $5 \%$ of those living in rural areas. ${ }^{3}$

Overweight and obesity are influenced by a variety of factors, including genetics, physical activity, diet, and socioeconomic status. One study in Bantul, Yogyakarta (2011) revealed that children who performed mediumto-high levels of physical activity less than one hour per day were five times more likely to develop obesity than those who performed medium-to-high levels of physical activity more than one hour per day. ${ }^{4}$ Several studies also indicated that rural children spend more time being active outdoors than children living in urban areas. ${ }^{5}$ Low levels of physical activity may be due to increased screen time activity among children. At present, children spend more time watching television and playing computer games, which leads to increased snacking habits. A highcalorie diet is an important contributor to childhood overnutrition. Eating fast food is also popular in urban areas due to its easy access and modern lifestyle. ${ }^{6}$ Study conducted among high school students in Yogyakarta showed that obesity in urban students was higher than for rural students because urban students had lower levels of physical activity and tended to consume fatty and high-calorie diets. ${ }^{7}$

Obese children have a high risk of developing obesity-related diseases such as cardiovascular disease, hypertension, type 2 diabetes, obstructive sleep apnea, asthma, and some malignancies. ${ }^{8}$ Impaired glucose tolerance ${ }^{9}$ and dyslipidemia ${ }^{10,11}$ have also been reported among obese Indonesian children. Therefore, the aim of this study was to compare the incidence of overnutrition among elementary school children between urban and rural areas in Pekanbaru and analyze its associated factors.

\section{Method}

This was an analytical observational study with a cross-sectional design. It was conducted in six elementary schools in Pekanbaru between April and May 2018. The study population was Pekanbaru elementary school students. The total sample size for this study was 250 students from three urban area schools and three rural area schools. The students were recruited using a quota sampling method whereby samples were selected based on inclusion criteria and in proportion to the population at interest. Urban and rural areas are defined according to Statistics Indonesia 2010. ${ }^{12}$ The inclusion criteria were elementary school children in grades four and five who had attended the school for at least one year and had provided informed consent to be included in the study. Grades four and five were chosen because they were better suited to cooperate with answering the questionnaire than younger students, while grade six elementary school students were omitted from this study as they were preparing for the national exam. The reliability and validity of the questionnaire was assessed on 30 elementary school students. Exclusion criteria were children with edema, ascites, disabilities, and those who suffer from acute or chronic infectious diseases.

Data including age, sex, maternal education and body mass index (BMI), physical activity, screen time, and diet habits were collected using the questionnaire. Mothers' education levels were categorized into low education (did not complete senior high school) and high education (completed senior high school or higher). The children's weights were obtained using a digital scale with an accuracy of $0.1 \mathrm{~kg}$. The children's heights were measured using microtoise with an accuracy of $0.1 \mathrm{~cm}$. Furthermore, BMI was calculated as the ratio of body weight in kilograms and square of height in meters. Child BMI was calculated and expressed as z-score using WHO Anthroplus software (Version 1.0.4). Nutritional status was determined according to the 2006 WHO Child Growth Standards for age and sex specific references. Mothers were asked to report their current body weight and height. Maternal BMI was calculated by dividing weight in kilograms by height in meters squared. Maternal BMI was categorized according to the WHO classification for the Asia-Pacific population. ${ }^{13}$

Physical activity and screen time were measured using a slightly modified questionnaire that had been used in previous studies. ${ }^{5}$ Physical activity consisted of outdoor and indoor physical activities. Indoor activities included activities spent inside the house and in the classroom, 
such as playing with friends, going up and down stairs, or doing homework. Outdoor activities included walking, running, playing with friends, or sports, if conducted outside. ${ }^{5}$ Screen time included time spent watching TV, working on a computer, playing computer games or using game consoles, both on school weekend days. Indoor, outdoor activities, and screen time were categorized into $\geq$ hours/day and $<2$ hours/day.

Diet was measured using a questionnaire that consisted of various questions such as main meal frequency and breakfast, snacking, sugary drinks, fast food, vegetable, and fruit consumption habits. Main meal frequency was classified into the following categories: 1 ) 1-2x/day; 2) 3x/day; and 3) >3x/day. Other diet habits, including snacking, sugary drinks, fast food, vegetable, and fruit intake were categorized as follows: 1$)$ never; 2) 1-3x/week; 3) 4-6x/week; and 4) every day, except as stated otherwise. ${ }^{5}$

Numerical data were presented as mean $\pm \mathrm{SD}$ whereas categorical data were presented as proportions. To compare urban and rural areas, Student's t-test or Mann Whitney $U$ test were used to compare numerical data as appropriate and Chi-square was used to compare categorical data. Association between independent variables (age, sex, physical activity, screen time, and eating habits) and dependent variable (overnutrition) was analyzed using a Chi-square test. Variables that resulted in p-value $<0.25$ in the bivariate analyses were included in multivariate analyses using multiple logistic regression models that were performed separately on urban and rural data. A variable of $p$-value $<0.05$ was deemed as statistically significant. This study was approved by the Ethical Review Board for Medicine and Health Research Faculty of Medicine Universitas Riau (Decree Number 472a/UN.19.5.1.1.8/UEPKK/ 2017).

\section{Results}

Table 1 shows the characteristics of research subjects. Sex distribution, proportion of overweight or obese children, screen time, indoor and outdoor activity, and maternal age did not differ between urban and rural areas. However, the average age of rural children was slightly younger compared to children in urban areas; rural children's mothers had lower levels of education, more children in the family, and a significantly lower mean BMI (p-value $<0.05$ ).

The relationship between indoor, outdoor, screen time activities and the incidence of overnutrition in urban and rural areas is shown in Table 2. The results showed that duration of outdoor activity was associated with the

Table 1. Characteristics of Research Subjects

\begin{tabular}{|c|c|c|c|c|}
\hline \multirow{2}{*}{ Variables } & \multicolumn{2}{|c|}{ Urban $(n=137)$} & \multicolumn{2}{|c|}{ Rural $(n=113)$} \\
\hline & n (\%) & $\operatorname{Mean} \pm$ SD & n (\%) & $\operatorname{Mean} \pm$ SD \\
\hline Age & & $10.77 \pm 0.86$ & & $10.49 \pm 0.72 a$ \\
\hline Male & $62(45.3)$ & & $52(46)$ & \\
\hline Female & $75(54.7)$ & & $61(54)$ & \\
\hline Overweight & $22(16.1)$ & & $14(12.4)$ & \\
\hline Obesity & $23(16.8)$ & & $11(9.7)$ & \\
\hline Screen time (hours/day) & & $2.07 \pm 1.41$ & & $1.82 \pm 1.34$ \\
\hline Indoor activity (hours/day) & & $1.19 \pm 0.93$ & & $1.35 \pm 1.41$ \\
\hline Outdoor activity (hours/day) & & $1.01 \pm 0.98$ & & $1.27 \pm 1.09$ \\
\hline Maternal age (years) & & $40.46 \pm 6.33$ & & $39.07 \pm 5.56$ \\
\hline Low-educated mothers & $96(70.1)$ & & $102(90.3) \mathrm{a}$ & \\
\hline High-educated mothers & $41(29.9)$ & & $11(9.7) \mathrm{a}$ & \\
\hline Number of children & & $3.02 \pm 1.21$ & & $3.33 \pm 1.32 \mathrm{a}$ \\
\hline Maternal BMI & & $24.49 \pm 3.42$ & & $23.12 \pm 3.74 a$ \\
\hline
\end{tabular}

Table 2. Association between Physical Activity, Screen Time, and Overnutrition in Urban and Rural Areas

\begin{tabular}{|c|c|c|c|c|c|c|c|}
\hline \multirow[t]{2}{*}{ Variable } & & \multicolumn{4}{|c|}{ Urban (n [\%]) } & \multicolumn{2}{|l|}{ Rural (n [\%]) } \\
\hline & & $\begin{array}{l}\text { Overnutrition } \\
\begin{array}{c}(\mathrm{n}=45) \\
\mathrm{n}(\%)\end{array}\end{array}$ & $\begin{array}{l}\text { Not Overnutrition } \\
(\mathbf{n}=92) \\
\mathbf{n}(\%)\end{array}$ & p-value & $\begin{array}{l}\text { Overnutrition } \\
\qquad \begin{array}{c}(\mathrm{n}=25) \\
\mathrm{n}(\%)\end{array}\end{array}$ & $\begin{array}{l}\text { Not Overnutrition } \\
(\mathbf{n}=\mathbf{8 8}) \\
\mathbf{n}(\%)\end{array}$ & p-Value \\
\hline \multirow[t]{2}{*}{ Indoor activity } & hours/day & $11(27.5)$ & $29(72.5)$ & 0.329 & $6(15.4)$ & $30(84.6)$ & 0.339 \\
\hline & $<2$ hours/day & $34(35.1)$ & $63(64.9)$ & & $19(24.7)$ & $58(75.3)$ & \\
\hline \multirow[t]{2}{*}{ Outdoor activity } & $\geq$ hours/day & $6(8.3)$ & $30(91.7)$ & 0.016 & $7(18.4)$ & $31(81.6)$ & 0.500 \\
\hline & $<2$ hours/day & $39(38.6)$ & $62(61.4)$ & & $18(24)$ & $57(76)$ & \\
\hline \multirow[t]{2}{*}{ Screen time } & $\geq$ hours/day & $27(35.1)$ & $50(64.9)$ & 0.531 & $13(21.3)$ & $48(78.7)$ & 0.822 \\
\hline & $<2$ hours/day & $18(30)$ & $42(70)$ & & $12(23.1)$ & $40(76.9)$ & \\
\hline
\end{tabular}


Table 3. Association between Diet Habits and Combined Overweight/Obesity in Urban and Rural Areas

\begin{tabular}{|c|c|c|c|c|c|c|c|}
\hline \multirow{3}{*}{ Variable } & \multirow{3}{*}{ Category } & \multicolumn{2}{|c|}{ Urban (n [\%]) } & \multirow{3}{*}{ p-Value } & \multicolumn{2}{|c|}{ Rural (n [\%]) } & \multirow{3}{*}{ p-Value } \\
\hline & & $\begin{array}{c}\text { Overweight/ Obesity } \\
(n=45)\end{array}$ & $\begin{array}{l}\text { Not Overweight/ obesity } \\
(\mathrm{n}=92)\end{array}$ & & $\begin{array}{r}\text { Overweight/ Obesity } \\
(\mathbf{n}=25)\end{array}$ & $\begin{array}{r}\text { Not Overweight/ obesity } \\
\qquad(\mathrm{n}=\mathbf{8 8})\end{array}$ & \\
\hline & & n (\%) & n $(\%)$ & & n (\%) & n $(\%)$ & \\
\hline \multirow[t]{3}{*}{ Main meal } & $1-2 x /$ day & $9(23.7)$ & $29(76.3)$ & \multirow[t]{3}{*}{0.281} & $4(23.5)$ & $13(76.5)$ & \multirow[t]{3}{*}{0.091} \\
\hline & $3 x /$ day & $33(35.5)$ & $60(64.5)$ & & 19 (20.4) & 74 (79.6) & \\
\hline & $>3 x /$ day & $3(50)$ & $3(50)$ & & $2(66.7)$ & $1(33.3)$ & \\
\hline \multirow{2}{*}{ Breakfast every day } & Yes & $35(33.7)$ & $69(66.3)$ & \multirow[t]{2}{*}{0.721} & $19(20)$ & $76(80)$ & \multirow{2}{*}{0.225} \\
\hline & No & $10(30.3)$ & $23(69.7)$ & & $6(33.3)$ & $12(66.7)$ & \\
\hline \multirow[t]{3}{*}{ Snacking } & 1-3x/week & 12 (22.6) & $41(77.4)$ & \multirow[t]{3}{*}{0.067} & $12(26.1)$ & 34 (73.9) & \multirow[t]{3}{*}{$0.05 \mathrm{c}$} \\
\hline & 4-6x/week & $4(26.7)$ & $11(73.3)$ & & $4(50)$ & $4(50)$ & \\
\hline & Every day & $29(42)$ & $40(58)$ & & $9(15.3)$ & $50(84.7)$ & \\
\hline \multirow{3}{*}{ Sugary drinks } & Never & $22(31.4)$ & $48(68.6)$ & \multirow{3}{*}{0.729} & $12(30)$ & $28(70)$ & \multirow{3}{*}{0.112} \\
\hline & 1-3x/week & $22(35.5)$ & $40(64.5)$ & & $8(14)$ & $49(86)$ & \\
\hline & Every day & $1(20)$ & $4(80)$ & & $5(31.3)$ & $11(68.7)$ & \\
\hline \multirow[t]{4}{*}{ Fast food } & Never & $3(9.1)$ & $8(80.9)$ & \multirow[t]{4}{*}{0.871} & $3(17.6)$ & $14(82.4)$ & \multirow[t]{4}{*}{0.883} \\
\hline & 1-3x/week & $35(33)$ & $71(67)$ & & $18(23.1)$ & 60 (76.9) & \\
\hline & 4-6x/week & $5(31.3)$ & $11(68.7)$ & & $3(9.1)$ & $8(80.9)$ & \\
\hline & Every day & $2(50)$ & $2(50)$ & & $1(14.3)$ & $6(85.7)$ & \\
\hline \multirow[t]{4}{*}{ Vegetable intake } & Never & $4(28.6)$ & $10(71.4)$ & \multirow[t]{4}{*}{0.863} & $0(0)$ & $1(100)$ & \multirow[t]{4}{*}{0.782} \\
\hline & 1-3x/week & $6(31.6)$ & $13(68.4)$ & & $3(18.8)$ & $13(81.2)$ & \\
\hline & 4-6x/week & $14(29.8)$ & $33(70.2)$ & & $6(18.2)$ & $27(81.8)$ & \\
\hline & Every day & $21(36.8)$ & $36(63.2)$ & & $16(25.4)$ & $47(74.6)$ & \\
\hline \multirow[t]{4}{*}{ Fruit intake } & Never & $2(50)$ & $2(50)$ & \multirow[t]{4}{*}{0.263} & $3(33.3)$ & $6(66.7)$ & \multirow[t]{4}{*}{0.506} \\
\hline & $1-3 x /$ week & $5(18.5)$ & $22(81.5)$ & & 7 (23.3) & $23(76.7)$ & \\
\hline & 4-6x/week & $22(33.3)$ & $44(66.7)$ & & $9(16.7)$ & $45(83.3)$ & \\
\hline & Every day & $16(40)$ & $24(60)$ & & $6(30)$ & $14(70)$ & \\
\hline
\end{tabular}

development of overnutrition in urban but not in rural areas $(p$-value $=0.016)$. Indoor activities and screen time were not significantly associated with a prevalence of overnutrition in both urban and rural areas.

The relationship between eating habits and the incidence of overnutrition in urban and rural areas can be seen in Table 3. The number of children who had a main meal as many as $1 \mathrm{x} /$ day was very small, hence this group was combined with the $2 \mathrm{x} /$ day group. In comparison with children who had a main meal 1-2x/day and 3x/day, urban and rural children who had the habit of eating a main meal $3 x /$ day were more frequently overnutrient. More urban children who had a daily breakfast developed overnutrition compared to those who skipped breakfast, while the opposite was the case for rural children. In comparison with other groups, overnutrient was frequently found in urban children who snacked every day and rural children who had a snacking habit of 4-6 $\mathrm{x} /$ day. Urban children who consumed sugary drinks every day and rural children who had sugary drinks 4$6 x /$ day were more likely to develop overnutrition compared to other groups. In comparison with other groups, overnutrition was frequently found in urban children who had fast food every day and rural children who had fast food 1-3x/day.

Rural and urban children who consumed vegetables every day were more likely to develop overnutrition compared to other groups. Urban children who consumed fruit daily and rural children who did not consume fruit were more likely to develop overnutrition compared to other groups. There was no significant association between diet, breakfast, snacking habits, sugary drinks, fast food, vegetable, or fruit consumption and the proportion of overnutrition in children living in urban and rural areas ( $\mathrm{p}$-value $>0.05$ ).

Based on the bivariate tests, several variables met the criteria for multivariate analysis ( $\mathrm{p}$-value $<0.25$ ); namely, outdoor activity and snacking habits for urban areas and frequency of main meal, breakfast, snacking, and sugary drinks habits for rural areas. These variables were then included in the multivariate analysis using a binary logistic regression test. Table 4 shows the results of the multivariate binary logistic regression tests on urban area data. Children who spent $<2$ hours/day doing outdoor activity were four times more likely to develop overnutrition than children who participated in outdoor activity 2 hours/day $(p$-value $=0.006)$. In addition, children who had a habit of eating snacks every day had a three times greater risk of developing overnutrition ( $p$-value $=$ 0.009). Table 5 shows the results of multivariate analysis on rural area data. Only main meal frequency was significantly associated with overnutrition in rural areas. 
Table 4. Results of Multivariate Analysis of Combined Overweight and Obesity in Urban Areas

\begin{tabular}{|c|c|c|c|c|}
\hline Variable & Category & p-Value & OR & $95 \%$ CI \\
\hline \multirow[t]{2}{*}{ Outdoor activity } & $>2$ hours/day & & ref & \\
\hline & $<2$ hours/day & 0.006 & 4.043 & $1.479-11.05$ \\
\hline \multirow[t]{3}{*}{ Snacking } & 1-3x/week & & ref & \\
\hline & 4-6x/week & 0.831 & 1.155 & $0.305-4.37$ \\
\hline & Every day & 0.009 & 3.058 & $1.322-7.076$ \\
\hline
\end{tabular}

Table 5. Results of Multivariate Analysis of Combined Overweight And Obesity in Rural Areas

\begin{tabular}{|c|c|c|c|c|}
\hline Variable & Category & p-Value & OR & $95 \%$ CI \\
\hline \multirow[t]{3}{*}{ Main meal } & $1-2 x /$ day & & ref & \\
\hline & $3 x /$ day & 0.289 & 2.747 & $0.425-17.751$ \\
\hline & $>3 x /$ day & 0.037 & 32.099 & $1.240-831.094$ \\
\hline \multirow{2}{*}{ Breakfast every day } & Yes & & ref & \\
\hline & No & 0.085 & 0.240 & $0.047-1.220$ \\
\hline \multirow[t]{3}{*}{ Snacking } & $1-3 \mathrm{x} /$ week & & ref & \\
\hline & 4-6x/week & 0.180 & 3.074 & $0.596-15.849$ \\
\hline & Every day & 0.168 & 0.472 & $0.162-1.373$ \\
\hline \multirow{3}{*}{ Sugary drinks } & Never & & ref & \\
\hline & $1-3 x /$ week & 0.084 & 0.382 & $0.128-1.138$ \\
\hline & Every day & 0.672 & 0.737 & $0.179-3.030$ \\
\hline
\end{tabular}

Children who had a main meal frequency of $>3 x$ day had a 32 times greater risk of becoming obese than children who only had a main meal $1-2 \mathrm{x} /$ day $(\mathrm{p}$-value $=0.037)$.

\section{Discussion}

This study shows that there was no difference in the prevalence of overnutrition among elementary school children between urban and rural areas in Pekanbaru. The proportions of overweight and obesity in urban areas were $16.1 \%$ and $16.8 \%$, respectively, whereas in rural areas, these same proportions were $12.4 \%$ and $9.7 \%$, respectively. The prevalence of obesity in this study was greater than the national figure reported in 2010 National Basic Research, which was $10.4 \%$ for urban areas and $8.1 \%$ for rural areas. ${ }^{14}$ One study conducted among elementary school children in Bali in 2012 reported that the proportion of overnutrition was $21 \%$ in urban areas and 5\% in rural areas. ${ }^{3}$

Socioeconomic level is one important factor that influences the prevalence of overnutrition and this is thought to account for the difference in overnutrition prevalence between urban and rural areas. There are several explanations as to why there was no difference in overnutrition prevalence between urban and rural areas in this study. The incidence of overnutrition in children in rural areas may have increased to the point that conditions are now almost equal to urban areas. Another possible explanation is this study's selection of rural areas that are still in close proximity to the city center, which may also affect the study results.

This study found differences in factors that contribute to overnutrition in children in urban and rural areas. The duration of outdoor activities and snacking habits were significant contributors to childhood overnutrition in urban areas, while the main frequency of a main meal was the only factor that affected the incidence of overnutrition in rural children. Urban and rural areas have different socioeconomic levels, demographics, and cultural characteristics. Rural residents are mostly farmers with a typically lower socioeconomic status than urban residents. This study also shows that, compared to urban areas, maternal education levels were lower and families tended to have more children in rural areas. This combination of low socioeconomic and educational levels has the potential to increase children's risk of obesity. These two conditions may hamper family access to healthy and balanced food choices, as well as to the tendency for mothers' knowledge of healthy lifestyles to be lower. Research in developed countries has shown that populations that are more at risk for developing overnutrition are groups with low income levels that generally live in rural areas. ${ }^{15,16}$

Physical activity is another possible factor accounting for the difference in the prevalence of overnutrition among children between urban and rural areas. Some studies show that children in rural areas have higher levels of physical activity than children in urban areas. ${ }^{5}$ In this study, outdoor activity has a significant role in the 
development of overnutrition in urban areas but not in rural areas. High amounts of screen time activity may prevent children from spending time participating in outdoor activities. Children are currently faced with a digital invasion of technology in the form of internet, electronic games, smartphones, and television media. ${ }^{17}$ Children's activities with gadgets, also known as screen time, have been reported to affect the incidence of obesity. ${ }^{18}$ Although most overweight/obese children spent $\geq 2$ hours/day playing with gadgets, the results of the analysis did not show any significant association between screen time and the incidence of overnutrition among children in urban and rural areas. In contrast, studies in Yogyakarta and Bantul in 2013 reported that children who spent time watching TV $\geq 2$ hours/day had a three times greater risk of developing obesity than children who watched TV $<2$ hours/day. ${ }^{19}$ To understand more about the effect of screen time on the prevalence of obesity, further research needs to be done using instruments that can accurately measure children's screen time activity.

In addition to physical activity, unhealthy diet is closely related to the development of childhood overnutrition. High-calorie diet (fast food and snacks), skipping breakfast, high sweetened drink consumption, 20 and low intake of vegetables and fruits 21 are factors that play an important role in the development of obesity in children. Many studies have shown that children who skip breakfast have a greater risk of developing obesity and even type 2 diabetes. ${ }^{22}$ In addition to breakfast habits, high consumption of soft drinks among children is also thought to contribute to the increased incidence of obesity in children around the world. ${ }^{20}$ The high sugar content in the form of fructose in soft drinks is considered more dangerous to health than glucose. High consumption of sugary drinks is also associated with the increased incidence of diabetes and cardiovascular disease, type 2 diabetes mellitus, and cardiovascular disease. ${ }^{23}$ Research in Bantul, Yogyakarta reported that obese children consumed more sweetened drinks than their non-obese counterparts. ${ }^{24}$ In contrast, this study did not find any significant association between eating habits (fast food, sugary drinks, and vegetable and fruit intake) and overnutrition in elementary school children. This study only measures the frequency of diet; therefore, further research is needed to compare eating habits between urban and rural children by measuring calorie intake quantitatively.

\section{Conclusion}

This study shows that outdoor activities and snacking habits are significant contributors to overnutrition among elementary school children in Pekanbaru's urban areas, while frequency of main meal is the only associated factor for overnutrition among rural children. This study also highlights that the lower education levels of mothers and other family members in rural areas may inhibit family access to healthy and nutritious food; this in turn could increase the risk of childhood obesity.

These data will inform practitioners and policy makers in the development of targeted intervention programs to tackle childhood obesity in both urban and rural areas. It is necessary to tailor community education programs on promoting healthy eating habits and increasing physical activity based on associated factors found in urban and rural areas.

\section{Acknowledgment}

The authors thank to the school principals, teachers, and all the students who participated in this study. This study was supported by a faculty research grant from the Faculty of Medicine, University of Riau 2017 (contract no. 32/UN19.5.1.1.8/UPPM/2018).

\section{References}

1. World Health Organization. Obesity and overweight. Geneva: World Health Organization; 2018. Available from: https://www.who.int/newsroom/fact-sheets/.

2. Kementerian Kesehatan Republik Indonesia. Riset Kesehatan Dasar 2013. Jakarta: Kementerian Kesehatan Republik Indonesia; 2013: 209.

3. Dewi M, Sidiartha I. Prevalensi dan faktor risiko obesitas anak sekolah dasar di daerah urban dan rural. Medicina. 2013; 44: 15-21.

4. Zamzani M, Hadi H, Astiti D. Aktivitas fisik berhubungan dengan kejadian obesitas pada anak Sekolah Dasar. Jurnal Gizi dan Dietetik Indonesia. 2016; 4(3): 123-128.

5. Do LM, Tran TK, Eriksson B, Petzold M, Nguyen CT, Ascher H. Preschool overweight and obesity in urban and rural Vietnam: differences in prevalence and associated factors. Glob Health Action. 2015; 8: 28615.

6. Johnson III JA, Johnson AM. Urban-rural differences in childhood and adolescent obesity in the United States: a systematic review and metaanalysis. Childhood Obesity. 2015; 11(3): 233-241.

7. Mahdiah M, Hadi H, Susetyowati S. Prevalensi obesitas dan hubungan konsumsi fast food dengan kejadian obesitas pada remaja SLTP kota dan desa di Daerah Istimewa Yogyakarta. Jurnal Gizi Klinik Indonesia. 2004; 1(2): 69-77.

8. Dietz WH. Health consequences of obesity in youth: childhood predictors of adult disease. Pediatrics. 1998; 101: 518-525.

9. Pribadi A, Subardja D, Rustama DF, Fadil R. Relationship between the degree of obesity and oral glucose tolerance in primary obese adolescents. Paediatrica Indonesiana. 2002; 42(11-12): 249-253.

10. Tangkilisan AH, Akune K. Some factors related to lipid profile in obese children at junior high schools in Manado. Paediatrica Indonesiana. 2007; 47(4): 166-171.

11. Himah R, Prawirohartono EP, Julia M. Association between obesity and lipid profile in children 10-12 years of age. Paediatrica Indonesiana. 2008; 48(5): 257-260.

12. Badan Pusat Statistik. Peraturan Kepala Badan Pusat Statistik Nomor 
37 Tahun 2010. Klasifikasi perkotaan dan perdesaan di Indonesia. Jakarta: Badan Pusat Statistik; 2010.

13. World Health Organization. Appropriate body-mass index for Asian populations and its implications for policy and intervention strategies. Lancet. 2004; 363: 157-163.

14. Kementerian Kesehatan Republik Indonesia. Riset Kesehatan Dasar 2010. Jakarta: Kementerian Kesehatan Republik Indonesia; 2010. p. 45.

15. Van Stralen MM, Te Velde SJ, Van Nassau F, Brug J, Grammatikaki E, Maes L et al. Weight status of European preschool children and associations with family demographics and energy balance-related behaviours: A pooled analysis of six European studies. Obesity Reviews. 2012; 13 (Suppl. 1): 29-41.

16. Sjöberg A, Moraeus L, Yngve A, Poortvliet E, Al-Ansari U, Lissner L. Overweight and obesity in a representative sample of schoolchildren exploring the urban-rural gradient in Sweden. Obesity Reviews. 2011; 12(5): 305-314.

17. Decelis A, Jago R, Fox KR. Physical activity, screen time and obesity status in a nationally representative sample of Maltese youth with international comparisons. BMC Public Health. 2014; 14: 664.

18. Robinson TN, Banda JA, Hale L, Lu AS, Fleming-Milici F, Calvert SL et al. Screen media exposure and obesity in children and adolescents. Pediatrics. 2017; 140(Suppl. 2): S97-S101.

19. Kesztyüs D, Traub M, Lauer R, Kesztyüs T, Steinacker JM. Skipping breakfast is detrimental for primary school children: cross-sectional analysis of determinants for targeted prevention. BMC Public Health. 2017; 17(1): 258

20. Matthews VL, Wien M, Sabaté J. The risk of child and adolescent overweight is related to types of food consumed. Nutrition Journal. 2011; 10 (1): 71.

21. Pereira MA, Erickson E, McKee P, Schrankler K, Raatz SK, Lytle LA et al. Breakfast frequency and quality may affect glycemia and appetite in adults and children. Journal of Nutrition. 2011; 141(1): 163-168.

22. Brown CM, Dulloo AG, Montani JP. Sugary drinks in the pathogenesis of obesity and cardiovascular diseases. International Journal of Obesity. 2008; 32(S6): S28-S34.

23. Lakoro Y, Hadi H, Julia M. Pola konsumsi air, susu dan produk susu, serta minuman manis sebagai faktor risiko obesitas pada anak sekolah dasar di Kota Yogyakarta dan Kabupaten Bantul. Jurnal Gizi dan Dietetik Indonesia. 2013; 1(2): 102-109. 